\title{
Phalangeal Microgeodic Syndrome の治療経験
}

\author{
高橋 良 輔* 富田雅人*宮田倫 明* \\ 尾㟝誠* 西 野 雄一朗**
}

【はじめに】 Phalangeal microgeodic syndrome（以後 PMS）は寒冷期に手指・足趾に紡錘状腫脹， 疼痛を来たす比較的稀な疾患である。今回，手指に発症した PMS の 2 例を経験したので報告する.【症 例】〈症例 1 〉 10 歳男児. 2 月中旬より左小指中節部の腫脹，疼痛を主訴に同年 3 月当科紹介受診. $\mathrm{X}$ 線 像にて骨吸収像を, MRIにて骨䯣浮腫性変化を認めた。確定診断目的に切開生検施行。細菌培養検査で は陰性, 病理検査にて PMS と診断した。 5 力月後に手指の腫脹及び骨変化は改善した。〈症例 2 〉 8 歳女 児. 2 月下旬より右小指中節部の腫脹，疼痛を主訴に同年 4 月当科紹介受診. 症例 1 と同様の症状及び画 像所見であり, PMS と診断した。経過観察のみで 5 カ月後に症状は改善した。【考察】PMS は寒冷刺 激による一過性骨内微小循環障害と考えられ，自然治癒し予後は良好である。寒冷期に X 線像にて骨吸 収像を伴う手指・足趾の腫脹に遭遇した場合，本疾患を鑑別疾患の 1 つとして考慮すべきである.

Key words : infant (小児), finger swelling (手指腫脹)

は じめに

Phalangeal microgeodic syndrome は 1970 年に Maroteaux が初めて “A microgeodic disease of unknown aetiology affecting the finger phalanges in infants.”と報告した疾患である。本疾患は一見， 臨床及び単純 X 線像において化膿性骨髄炎及び骨腫 瘍梯の所見を呈するが, これらの疾患とは異なり予後 良好な一途を辿る。 今回, 我々は本疾患と考元られる 2 例を経験したので報告する.

\section{症}

例

症例 $1: 10$ 歳 男児

2 月中旬より特に誘因なく左小指中節部疼痛・発赤 · 紡鍾様腫脹を自覚した（図 1)。近医外科を受診し保 存的治療を施されたが改善なく近医整形外科を受診し た。単純 X 線像にて骨腫瘍が疑われ当院紹介受診と なった,

初診時所見 : 左小指中節部にしもやけ様の疼痛・発 赤・紡鍾様腫脹を認めた（図 1)。運動制限や感覚障 害はなく腋窩リンパ節も触知しなかった。血液検査で は白血球 5300 個 $/ \mu \mathrm{l}, \quad \mathrm{CRP} 0.00 \mathrm{mg} / \mathrm{dl}$ と炎症所見は 認めなかった。単純 X 線像にて左小指中節骨骨幹部

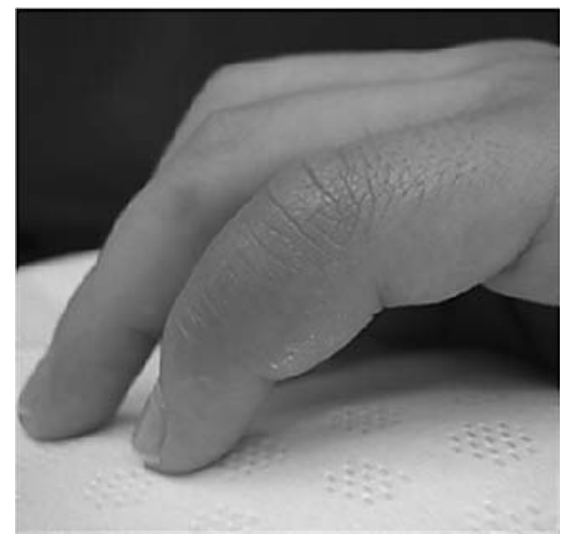

図 1 小指中節部の発赤・腫脹

に小円形骨透膫像と近位骨幹端皮質骨の辺縁不整像を 認めた（図 $2 \mathrm{a}, b)$ ）ＭRI 像では単純 X 線像とは一 致しない小指全体に $\mathrm{T} 1$ 強調画像にて低信号, $\mathrm{T} 2$ 強 調画像にて高信号の異常信号を示し, 周囲の軟部組織 に紡錘状の腫脹と異常信号を呈した。また小指中節骨 の骨膜下に沿う異常信号及び中節骨近位骨幹端骨皮質 の不整を認めた（図 2 c).

経過 : 骨䯣炎の可能性も考え抗生剂内服を行ったが 症状の軽減はみられなかつた。また骨腫瘍の可能性も

\footnotetext{
* 長崎大学整形外科

** 長崎労災病院整形外科
} 


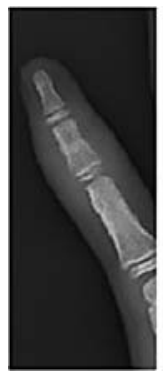

a

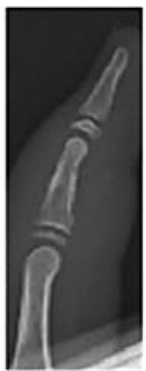

b

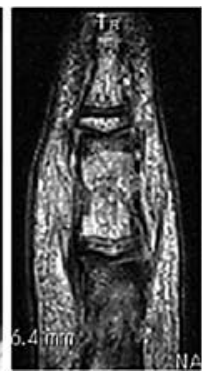

c

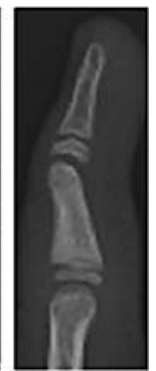

d
図 $2 \mathrm{a}$ : 初診時単純 $\mathrm{X}$ 線正面像 $\mathrm{b}$ : 初診時単純 X 線側面像 c : 初診時 MRI 正面像 $\mathrm{d}: 5$ 力月後単純 $\mathrm{X}$ 線側面像

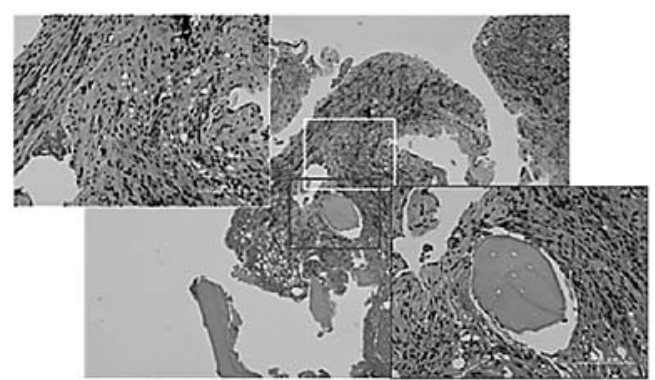

図 3 炎症細胞浸潤や細菌は認めず, 壊死骨と周囲に 壞死した骨髄組織及び脂肪組織を認めた。

骨組織には osteocyte を認めず壊死骨と考えら れる.
否定できず診断確定のため切開生検を施行した．手術 所見は皮質骨が带状に欠損しており海綿骨が露出して いた．採取した組織の肉眼所見はゼリー状の組織と正 常骨組織が混在していた。採取した検体を病理組織検 查に提出したところ, Bone necrosis and granulation tissue formation, bone of hand, biopsy の所 見で腫瘍性変化, 炎症細胞の浸潤や細菌は認めなかつ た（図 3)。また培養検査も陰性であった，臨床像， 画像所見, 組織診より Phalangeal microgeodic syndrome と診断した. 生検後 3 力月, 症状は軽快し単 純 X 線像は生検後 5 力月で改善を認めている（図 2). 症例 $2: 8$ 歳 女児

2 月下旬より症例 1 と同様に特に誘因なく右小指中 節部疼痛・発赤・紡鍾様腫脹を自覚し近医整形外科を 受診した．血液検查では炎症所見等の異常所見は指摘 されず，単純 X 線像及び MRI 像にて骨腫瘍を疑われ 当院紹介受診となった.

初診時所見 : 右小指中節部に疼痛・発赤・紡鍾様腫 脹を認めた．運動制限，感覚障害はなく肘窩部・腋窩 部・鎖骨上部に明らかなリンパ節は触知しなかった。 単純 X 線像にて右小指中節部骨幹端部に小円形骨透 瞭像と骨幹部皮質骨の辺縁不整像を認めた（図 $4 \mathrm{a}$, b)。また MRI では症例 1 同様に小指全体に $\mathrm{T} 1$ 強調 画像にて低信号, T2 強調画像にて高信号の異常信号 を呈していた（図 4)。症状は約 1 力月前の前医受診 時と比較すると改善傾向にあった.

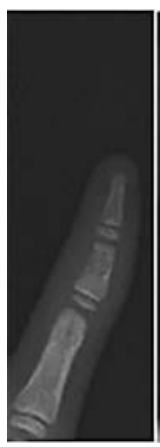

a

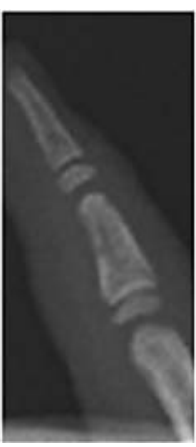

$\mathrm{b}$

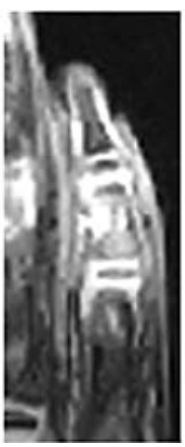

c

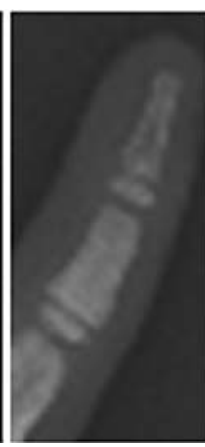

d

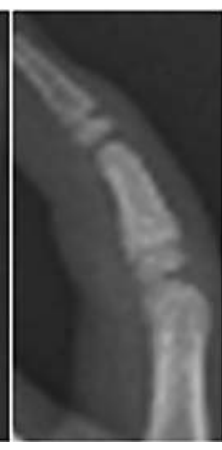

e

図 $4 a$ : 初診時単純 X 線正面像

$\mathrm{b}$ : 初診時単純 X 線側面像

$c$ : 初診時 MRI

$\mathrm{d}$ : 5 力月後単純 X 線正面像

e : 5 力月後単純 X 線側面像 
経過：症例 1 と同じ臨床像, 単純 X 線像, MRI 像 を呈していたため, Phalangeal microgeodic syndrome を最も考え経過観察を行った。症状は発症か ら 3 力月で軽快傾向を示し, 単純 X 線像も当院初診 から 5 カ月で改善を認めている(図 4).

$$
\text { 考察 }
$$

今回，我々が経験した 2 症例は，寒冷期発症で乳幼 児の手指にしもやけ様の疼痛・発赤・紡錘様腫脹を呈 しており, 単純 X 線にて指節骨小円形の骨透瞭像を 認めた，骨髄炎及び骨腫瘍が疑われ特に 1 症例目に対 しては抗生剤の投与及び切開生検術を施行した。しか し， 2 症例とも全身状態は良好で血液検査上炎症所見 に乏しく，数か月後に自然軽快しており，Maroteux らの報告した Phalangeal microgeodic syndrome の症例と一致し, 我々もこの範疇であると考えた ${ }^{6)}$.

本疾患名である “geode”とは晶質，晶洞石を意 味する。前田, 森本, Yamamoto らは Phalangeal microgeodic syndrome の単純 $\mathrm{X}$ 線像所見として指 骨骨幹部に “microgeode” すなわち径 $1 \mathrm{~mm}$ 程度の 小さな円形の斑点状骨透瞭像及び辺縁不整な貪食像と 骨膜性反応を呈すると報告している5779)10)，我々の 2 症例はともに $1 \mathrm{~mm}$ 程度の小円形骨透瞭像を呈し皮 質骨の辺縁不整像を認め森口らの報告と同様の所見で あった.また, MRI 像に関して Fujita, Yamamoto らは本症例の所見として単純 $\mathrm{X}$ 線像の病変とは一致 しない瀰漫性異常信号を呈すると報告しており ${ }^{19910)}$, 我々が経験した 2 症例も単純 X 線像では中節骨のみ に異常を認めたが MRI 像では小指全体の涵漫性異常 信号を呈しており Fujita らの報告と矛盾しない所見 だつた.

本疾患の診断に関して, 鑑別すべきものとしては骨 髄炎, 骨腫瘍, 結核, サルコイドーシス等が挙げられ る. 我々の 2 症例においても骨髄炎及び骨腫瘍との鑑 別には苦慮した。前田らが報告するように市，骨髄炎 との鑑別には単純 X 線像が有用で, Phalangeal microgeodic syndrome では単純 X 線像にて小円形 骨透瞭像と側面で皮質骨の辺縁不整像を同時に認める のに対し，骨髄炎では同時に認めることない。 また, 骨腫瘍との鑑別には MRI が有用で, Phalangeal microgeodic syndrome では MRI で単純 X 線像とは 一致しない広汎な異常信号が認められる.
本症例の病理組織学的所見に関して, Kaibara や 森本らは骨量, 骨䯣腔ともに壊死性変化を認め, 炎症 所見は認めないと報告している37). 今回我々は 1 症例 目に対し切開生検術を行い病理組織学的検査を施行し た. 病理所見は osteocyte を認めず壊死骨と周囲に壊 死した骨髄組織及び脂肪組織を認めたが，炎症や感染 を疑わせるような所見はみられなかつた。

病因としては未だ不明であるが前述したように寒冷 期に発症することが多く，また手指・足趾に生じるた め一過性の循環障害が最も支持されている.ただし, Viseux らが報告するように比較的温暖な地域での発 症例の報告や未節骨部よりも基節骨部に発症すること より循環障害によるものではなく，アレルギー説，感 染説等や自律神経異常等も考えられている ${ }^{8)}$. 治療は 特に必要とせず, 予後は 6 力月以内に自然治癒すると 言われているが, 近年, 病的骨折, 変形治癒例や難治

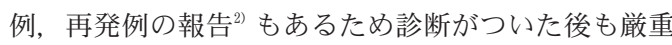
な経過観察が必要と考える.

\section{結語}

今回，比較的まれな Phalangeal microgeodic syndromeの 2 例を経験した。特徵的な臨床像及び画像 所見を呈するため，本疾患を念頭に置けば診断は容易 に可能である.

\section{参 考 文 献}

1) Fujita, A., et al.: Phalangeal microgeodic syndrome: findings on MR imaging. AJR, $173: 711-712$, 1999.

2) Inoue, G., et al.: Microgeodic disease affecting the hands and feet of children. J. Pediatr. Orthop., 11 : 59-63, 1991.

3) Kaibara, N., et al.: Phalangeal microgeodic syndrome in childhood: report of seven cases and review of the literature. Eur. J. Pediatr., 136 : 41-46, 1981.

4) 柏 薰里ら：体操選手の両足趾に生じた microgeodic disease の 1 例. J. Sports Injury, 11: 47-49, 2006.

5）前田元朗, 江木素子, 古谷喜義 : Microgeodic disease の 1 例. 日皮会誌, $114(2): 169-172,2004$.

6) Maroteux, P.: Cinq observations d'une affection microgeodique des phalages du nourrisson d'etiologie inconnue. Annales de Radiologie, 13 : 229236, 1970.

7）森本典夫ら：Microgeodic disease の 5 症例. 整外と 災外, 33(1) : 230-233, 1984.

8) Viseux, V., et al.: Phalageal microgeodic syn- 
drome and pine procesionary caterpillar. Eur. J. Dermatol., 13(5) : 497-499, 2003.

9) Yamamoto, T., et al.: Phalageal microgeodic syndrome: MR appearance.Skeletal Radiol., 30 : 170-172,
2001.

10) Yamamoto, T., et al.: Phalangeal microgeodic syndrome resulting in rapid digital shortening. Clin. Orthop. Relat. Res., 424 : 191-193, 2004. 